10. Pieshkova, V. (2016). Madrigal K. Monteverdi «Hor-che'l ciel e la terra» ("The time when heaven and earth»): features of the embodiment of the poetic text. Kyyivs'ke muzykoznavstvo 56, pp. 79-85 [in Russian].

11. Schip, S. (2011). Methodological significance of the doctrine of musical rhetoric in german and ukrainian musicology. Kyyivs'ke muzykoznavstvo 37. pp. 23-49 [in Russian].

12. Bartel, D. (1997). Musica Poetica: Musical-Rhetorical Figures in German Baroque Music. University of Nebraska Press. 471 p. [in English].

13. Buelow, G. J. (1980). Music and Rhetoric in The new Grove dictionary of music and musicians 15. pp. 793-803 [in English].

14. Cipollone E. (2006). Rhetoricians music. Among the figures of Sciarrino, Unités Sémiotiques Temporelles and Baroque Figurenlehren. Anno accademico. Available at: http://elvio.cipollone.free.fr/papers/MusicaRhetoricans.pdf [in Italian] [Accessed 01.02.2018].

15. Marchioro, G. (2016). The music of the soul. Libreria universitaria edizioni, Limena (PD). 174 p. [in Italian].

16. Restani,D. Music and rhetoric between Greece and Rome. Available at: http://www.oilproject.org/lezione/musica-e-retorica-tra-grecia-e-roma-20116.html [in Italian] [Accessed 16.02.2018].

17. Solci, R. Musical rhetoric and its symbolic and expressive architectures. Available at: http://websolci.altervista.org/attachments/article/13/ADR-Parte-05-a

La\%20Retorica\%20musicale.pdf [Accessed 30.10.2017].

УДК 787.2

ORCID: 0000-0002-7205-6981

Антон Городецький,

аспірант кафедри історії світової музики Національної музичної академї Украӥни ім. П. І. Чайковського вул. Архітектора Городеиького, 1-3/11, 02000, Київ, Україна

Anton Horodetskyi, Postgraduate at the Department of History of World Music, Ukrainian National Tchaikovsky academy of music, 1-3/11 Architect Gorodetsky St., Kyiv 02000, Ukraine

\title{
АЛЬТОВА МІНІАТЮРА У ТВОРЧОСТІ РЕБЕККИ КЛАРК
}

Мета роботи. Визначення особливостей індивідуального стилю англійської композиторки XX ст. Р. Кларк крізь призму іï альтових мініатюр. Методологія дослідження включає в себе застосування аналізу, синтезу, індукції, дедукції та аналогії. Наукова новизна роботи полягає в тому, що твори композиторки у жанрі альтової мініатюри на сьогоднішній день $є$ зовсім не дослідженими у вітчизняному та малодослідженими у світовому музикознавстві. Висновки. Дане дослідження може сприяти більш активному залученню творів Р. Кларк до концертного репертуару, стати імпульсом для подальших досліджень у галузі інструментальної мініатюри XX - початку XXI ст. 
Ключові слова: альт, альтова мініатюра, англійське музичне відродження, Ребекка Кларк.

Viola miniature in Rebecca Clarke creation. Objective. The identification of the individual style features of the English composer of the XXth century - R. Clark, through the prism of her viola miniatures. The methodology of the study includesthe application of analysis, synthesis, induction, deduction and analogy. The scientific novelty of the study lies in fact that the works of this composer in genre of viola miniature are not presented in Ukrainian and little presented in the world musicology. Conclusions. This study may contribute to the more active involvement of R. Clarke's works in the concert repertoire, can become an impulse for further researches in the field of instrumental miniatures of the XX-th and early XXI-st centuries.

Key words: viola, viola miniature, English Musical Renaissance, Rebecca Clarke.

Альтовая миниатюра в творчестве Ребекки Кларк. Цель работы. Определение особенностей индивидуального стиля английского композитора ХХ в. Р. Кларк сквозь призму её альтових миниатюр. Методология исследования состоит в применении анализа, синтеза, индукции, дедукции и аналогии. Научная новизна работы заключается в том, что произведения композитора в жанре альтовой миниатюры на сегодняшний день являються вовсе не исследованными в отечественном и мало исследованными в мировом музыковедении. Выводы. Данное исследование может способствовать более активному вовлечению произведений Р. Кларк в концертный репертуар, стать импульсом для дальнейших исследований в области инструментальной миниатюры XX-начала XXI в.

Ключевые слова: альт, альтовая миниатюра, английское музыкальное возрождение, Ребекка Кларк.

Постановка проблеми. Перші десятиліття ХХ ст. стали переломним періодом в історії європейського альтового мистецтва. Грандіозні еволюційні процеси, які відбувалисятоді у симфонічній та камерній музиці,зумовили значне ускладнення оркестрових та ансамблевих партій, індивідуалізацію кожного голосу партитури. Це у повній мірі стосується і альта.

Якщо буквально декілька десятиліть тому Р. Вагнер стверджував, що «...у великому оркестрі, який має вісім альтистів, був лише один виконавець, який міг заграти доволі складні пасажі в одній із моїх пізніх партитур» [7, c. 211], то відтепер культурні обставини змушують змінити ставлення виконавців до цього інструменту. 3'явилася необхідність його глибинного та систематичного вивчення. Це зумовило появу у даний період окремих 
класів альта у провідних європейських консерваторіях, формування різних національних альтових шкіл, оновлення альтового репертуару.

До початку XX ст. сольний альтовий репертуар був представлений здебільшого творами великої форми. Натомість мініатюра була доволі рідкісним явищем, на противагу фортепіанній та скрипковій музиці. Серед найбільш відомих альтових мініатюр XIX ст. можна згадати цикл 3 чотирьох п’єс Р. Шумана для альта і фортепіано «Мӓrchenbilder» («Казкові картини») op. 131 (1851), «Romance Oubliée» («Забутий романс») Ф. Ліста (1880) та ще декілька прикладів. Але, все одно, у цій галузі альтового репертуару спостерігалася певна прогалина.

Значення мініатюри для концертного репертуару інструменталіста важко переоцінити. Вона органічно «вписується» у програми вечорів камерної музики, є чудовим доповненням до творів великої форми, ідеальним варіантом для виконання «на біс». Жанрова сфера мініатюри є доволі складною, як для композиторів так і для виконавців, оскільки вимагає від обох філігранної відшліфовки кожної деталі.

Втім, інструментальна мініатюра на сьогоднішній день залишається малодослідженим явищем у світовому та вітчизняному музикознавстві. Відомий російський дослідник фортепіанної мініатюри доби романтизму К. Зенкін писав: «Поняття мініатюра, яке давно увійшло в лексикон музикантів-теоретиків і практиків, ще не перетворювалося на предмет теоретичного аналізу. Розмаїття та різноплановість явищ, охоплених цим поняттям (у тому числі й велика кількість жанрів) утворюють особливу об’єктивну складність дослідження та збільшують його актуальність» [1, с. 3].

Але на початку ХX ст. поряд із альтовими творами великої форми 3'являються ймініатюри. Англійська композиторка та альтистка Ребекка Кларк (1886-1979) однією з перших звернулася до цієї сфери. Будучи незаслужено маловідомою (про причини цьогоговоритиметься далі), Р. Кларк, як композиторка, має солідний творчий доробок обсягом більше, ніж 90 творів, який включає в себе камерно-інструментальні, камерно-вокальні (близько 55 пісень) та хорові композиції. Твори за участю альта становлять майже половину іï камерно-інструментальної музики. Усі вони, за винятком Сонати для альта і фортепіано, можуть бути віднесені до сфери інструментальної мініатюри. Саме вони утворюють головний предмет дослідження даної статті, адже альтова мініатюра композиторки зовсім не засвоєна вітчизняним та мало засвоєна світовим музикознавством. Це зумовлює актуальність та наукову новизну даної статті. Альтові мініатюри Р. Кларк викликають надзвичайний науковий інтересще і через наступні причини: 
1) альт для Р. Кларк був другим (виконавським) «я», потужним засобом самовираження, тож можна припустити, що своїм альтовим творам вона надавала особливого значення;

2) це той, надзвичайно рідкісний для музики $\mathrm{XX}$ ст. випадок, коли композитор, який створює альтову музику, пише іiї з розрахунку на власні виконавські сили;

3) твори Р. Кларк є абсолютно унікальним для першої половини $\mathrm{XX}$ ст. прикладом того, як у альта вперше з'являється «жіноче обличчя». Л. Кертіс 3 цього приводу писала наступне: «Ребекка Кларк <..> була однією з тих унікальних жінок, чия кар'єра як композиторки та альтистки відчинила двері для наступних поколінь жінок-музикантів» [4, с. 11];

4) альт був присутній у житті Р. Кларк-виконавиці протягом більше ніж трьох десятиліть, фактично паралельно ії творчій діяльності. Альтові твори стоять як біля витоків, так іпоряд із завершенням іiі композиторського шляху.

Виходячи 3 вищезазначеного, формується мета нашої статті визначення особливостей індивідуального композиторського стилю Р. Кларк крізь призму їі альтових мініатюр.

Аналіз останніх досліджень $\boldsymbol{i}$ публікацій. У процесі роботи над статею було опрацьовано монографію сучасної американської музикознавці, активної дослідниці творчості Р. Кларк - Ліан Кертіс «Хрестоматія Ребекки Кларк» (Liane Curtis «A Rebecca Clarke Reader») 2004 р., яка на сьогоднішній день залишається чи не єдиним дослідженням життя і творчості композиторки, а також іiї статтю у «The Musical Times» за 1996 р. - «Випадок ідентифікації: рятуючи Ребекку Кларк (Acase of identity: rescuing Rebecca Clarke»). Відбулось ознайомлення з дисертацією американського альтиста Грегорі Люса «Британський альтовий репертуар першої половини XX ст.» (Gregory R. Luce «British viola repertoire of the first half of the twentieth century»), в якій, серед інших, розглядаються й альтові твори композиторки. Серед вітчизняних робіт слід відмітити статтю М. Карапінки «Камерно-ансамблева альтова соната у творчості англійських композиторів початку XX століття» 2015 р., у якій мова йде i про Сонату для альта і фортепіано Р. Кларк, що є чи не єдиним прикладом звернення до ії творчості вітчизняних вчених.

Відстежити хронологію створення та публікації, обставини першого виконання альтових творів допоміг повний список іiі композиторської спадщини, розміщений на сайті, створеному Спільнотою Р. Кларк (Тhe Rebecca Clarke Society). Загальний контекст даного періоду в історії альта 
відтворено за допомогою фундаментальної монографії Моріса Райлі «Історія альта, том I» 1993 p. (Maurice W. Riley The history of the viola, V. I).

Методи дослідження. У процесі роботи над матеріалами даної статті нами були застосовані такі методи, як аналіз, синтез, індукція, дедукція та аналогія.

Викладення основного матеріалу дослідження. Англійська композиторка та альтистка Ребекка Кларк народилася 27 серпня 1986 р. у передмісті Лондона - Херроу. 31902 по 1905 рр. вонанавчається у класі скрипки Королівської музичної академії. 31907 р. Р. Кларк продовжила навчання у Королівському музичному коледжі в класі композиції одного 3 головних ініціаторів англійського музичного відродження Чарльза Станфорда. Саме він порадив Р. Кларк замінити скрипку на альт. Вона брала уроки узасновника англійської альтової школи - Лайонела Тертіса.

Через конфлікт з батьком у 1910 р. була змушена покинути навчання та самостійно забезпечувати себе грою на альті. Р. Кларк стає учасницею жіночого струнного квартету, починає грати в оркестрі Генрі Вуда «Куінс Холл», ставши однією з перших жінок у цьому колективі. У 1916 р. Р. Кларк їде до США з концертами.

У 1919 р. на композиторському конкурсі, який проводила відома покровителька музичного мистецтва Елізабет Кулідж у рамках створеного нею Беркширського фестивалю, Соната для альта і фортепіано Р. Кларк була удостоєна другої премії, розділивши ії з ще одним альтовим твором - Сюїтою Е. Блоха. Важливими подіями у житті Р. Кларк-виконавиці у цей період $є$ іiі концерти на Гавайських островах 1918-1919 рр. (разом 3 подругою віолончелісткою Мей Макл) та турне по британських колоніях у 1923 р. У 1924 р. Р. Кларк повертається до Лондону, багато виступає у концертах камерної музики, у тому числі у складі заснованого у 1927 р. Англійського ансамблю, який представляв собою жіночий фортепіанний квартет.

3 початку Другої світової війни Р. Кларк переїжджає до США, де мешкатиме до кінця життя. У 1944 р. вона одружується 3 піаністом Джеймсом Фріскіном - своїм колишнім однокурсником. 31954 р. вона припиняє композиторську діяльність, за винятком редагувань деяких своїх ранніх творів. Померла Р. Кларк у Нью-Йорку у 1979 р.

Маловідомість імені Р. Кларк для широкого загалу аж ніяк не пов'язана з якістю їі музики та виконавським професіоналізмом. Л. Кертіс пише про творчість композиторки наступне: «Вивчення іï робіт, однак, виявляє композитора надзвичайного таланту, а вивчення іiі життя $\epsilon$ свідоцтвом її значного внеску до камерної музики» [4, с. 11]. Якщо це так, то у чому ж тоді причини подібного забуття? 
У період творчої активності Р. Кларк жінки тільки починали набувати рівних прав з чоловіками у суспільстві. Існував цілий ряд професій, які вважалися «не жіночими», серед них і музика. Для того, щоб жінці зробити успішну музичну кар'єру, потрібно було активно відстоювати свої права. Однак «революційність» не була притаманна характеру Р. Кларк. Вона виховувалася у пізньо-вікторіанську добу, іiі батько був доволі жорсткою людиною. Це з дитинства сформувало певні риси характеру Р. Кларк суворий кодекс поведінки, сильну етику, працелюбність, поміркованість, визнання того місця у житті, що нав'язувалося соціумом.

У іiі подальшій музичній кар'єрі це зумовило занижену самооцінку власної творчості, відсутність самореклами. Як наслідок, переважна більшість іiі творів так і залишились неопублікованими за життя композиторки, а побачили світ тільки у кінці XX-на початку XXI ст. Потяг до камернізації у композиторській (у іiі доробку немає жодного оркестрового твору) та у виконавській діяльності, на нашу думку, також $\epsilon$ одним із проявів впливу вищезазначених чинників.

Втім, внутрішній творчий потенціал Р. Кларк, іï високий професійний рівень, вочевидь, заслуговували інших масштабів. Неможливість їх реального втілення у великих музичних формах призвела до максимального поглиблення у малих. «Виважений лаконізм висловлювання, відчуття напруженості музичного часу, стрункість пропорцій стали символами музичного інтелекту композиторки», - так характеризує її творчість М. Карапінка [2, с. 114].

Р. Кларк $є$ яскравою представницею англійського музичного відродження. Це виражається перш за все у яскравій національній приналежності iï музики, опорі на фольклор, навіть використанні оригінальних народних мелодій. Ця риса іiі творчості не зникає і після фактичної еміграції. Хоча й зустрічаються думки про те, що іï творча спадщина належить двом країнам - Англії та США, на нашу думку, музичне коріння Р. Кларк назавжди залишилося саме в Англії. Англійкою вона залишається i з огляду на бездоганний музичний смак, відчуття форми, культуру вираження емоцій, певною мірою консерватизм.3 англійським музичним відродженням іiї пов'язує також відчутний вплив імпресіонізму (особливо творчості К. Дебюссі), інтерес до хорової музики, а також прояв, особливо в кінці творчого шляху, неокласичних тенденцій.

Камерно-інструментальні твори за участю альта присутні у іiі доробку протягом майже усього композиторського шляху, який тривав приблизно з 1903 і до середини 50-х рр. Щоправда, в період між 1921 та 1941-ми pр. Р. Кларк нічого не писала для цього інструменту, але тоді 
взагалі спостерігався спад іiі композиторської діяльності. Ми вирішили зосередити увагу на п’єсах для альта і фортепіано, адже саме такий склад дозволяє максимально розкрити можливості кожного інструменту.

Колискова (1909) $є$ першим альтовим твором Р. Кларк, який відноситься ще до періоду навчання. Звернення до даного жанру не є поодиноким у творчості композиторки. У iі альтовій музиці можна зустріти ще два аналогічних приклади. 3 одного боку, цей жанр є одним із основних у фольклорі будь-якої країни, з іншого ж, інтерес до колискової в інструментальній музиці був характерним для періоду романтизму (як i звернення до сфери інструментальної мініатюри взагалі). Також це може вказувати i на вплив вокальної творчості композиторки (яка займала важливе місце у ii творчому доробку) на ii інструментальні твори, трактування інструментальної мініатюри як своєрідної «пісні без слів».

П'єса написана у складній тричастинній реприз ній формі 3 невеличким фортепіанним вступом (перші два такти) та кодою (такти 4857). Основним музичним матеріалом $\epsilon$ тема першого розділу, яка викладена у партії альта. Написана у невеличкому квантовому амбітусі, вона має вокальну природу і дійсно нагадує колискову пісню. Р. Кларк розвиває ऑii шляхом обернення, застосовує ритмічне варіювання прийоми, характерні для фольклору, - змінює фактуру супроводу у середньому розділі. П'єса майже повністю витримана у нюансах «mp-рр», нюанс «f» 3'являється у фортепіанній партії лише у такті 41 (він розповсюджується і на альтову партію).

Основна тональність п’єси - a-moll. Ця тональна основа чітко відчувається протягом твору, незважаючи на своєрідне «ладове мерехтіння», яке утворює часта зміна терцієвого тону акордів.

У «Колисковій» Р. Кларк чудово використовує можливості альта, представляючи інструмент у всіх регістрах - від гранично низького («ре» малої октави) до достатньо високого (натуральний флажолет на «ля» третьої октави). Вона всіляко розфарбовує ці регістри додатковими прийомами - використанням тих самих натуральних флажолетів, проведеннями теми на одній струні (відповідно «соль» та «ре»).

Вартує уваги іфортепіанна партія твору. Тут не випадково застосовується словосполучення «фортепіанна партія», адже фортепіано у даному випадку не є супроводжуючим інструментом - це активний учасник музикування, у його партії, що написана дуже фахово, міститься ряд важливих підголосків. Прийом «арпеджіато» у крайніх розділах, а також фігурації секстолями у середньому ніби імітують гру давніх щипкових інструментів, які акомпанували співу, як, наприклад, кельтська арфа. 
Р. Кларк застосовує ще один важливий прийом,який згодом стане характерним майже для всіх ï творів для альта і фортепіано - вона виписує альтову партію у регістрі, що знаходиться посередині між регістрами правої та лівої руки піаніста. Це, з одного боку, не виводить альтову партію на передній план, але, з іншого, дозволяє злитися цим інструментам у єдине ціле, бути рівноправними учасниками камерного музикування.

Вплив імпресіонізму виражається у тяжінні Р. Кларк до використання різноманітних звукових фарб i типових для творчості К. Дебюссі акордових послідовностей у фортепіанному супроводі.

Колискова на старовинну ірландську мелодію (1913) - це другий твір Р. Кларк, написаний для альта. Вона знову звертається до зазначеного жанру, але цього разу бере за основу оригінальну ірландську народну мелодію із збірки «Тhe complete Petrie collection of ancient Irish music» («Повне зібрання давньої ірландської музики Петрі») у редакції Ч. Станфорда. Якщо попередня п’єса $є$ досить вільною трактовкою жанру та певним чином виходить за його межі, то у випадку з другою п’єсою все навпаки. Звісно, у значній мірі це відбувається завдяки використанню оригінального матеріалу, але важливим $є$ i те, яким чином даний матеріал оформлено.

П'єса фактично заснована на двох темах. Перша викладена у фортепіанному вступі у перших трьох тактах. На ній побудовано всю фортепіанну партію. Специфічне ладове забарвлення, яке утворюється за рахунок підвищення у тональності Des-dur IV ступеню та пониження терцієвого тону, підкреслюючи таким чином інтервал збільшеної секунди, посилює народний колорит п’єси (лад, що виникає, є наближеним до лідійського). Низхідні секундові інтонації у даному випадку мають швидше нейтральне емоційне забарвлення, не привносячи інтонації плачу. Постійно повторюючись, тема створює гіпнотичний, заколисуючий ефект, який підсилений авторським позначенням характеру «simply and monotonously» (просто та монотонно).

Друга тема, вочевидь та сама старовинна ірландська, проводиться у альта від моменту його вступу. Вона має невеличкий амбітус, що не виходить за межі великої терції - дуже типовий для народних колискових. У тактах 15-20 у альта також проводиться тема 3 фортепіанної партії. У репризному розділі форми, що наближена до простої тричастинної, відбувається тиха кульмінація («мі бемоль» третьої октави). Кода (такти 39-50) звучить як відголосок початкового настрою.

У цій п’єсі Р. Кларк розширює темброву палітру. У альта протягом всієї п’єси діє позначка «соn sord.» (із сурдиною), а у фортепіано - «una corda» (на лівій педалі). Альт фактично показаний у всіх трьох регістрах. 
Перше проведення теми відбувається у середньому регістрі, на струні «соль». У репризі тема починається у низькому регістрі на струні «до», поступово переходить у середній, а під час вищезгаданої тихої кульмінації переміщується у верхній регістр. У останньому такті у альта звучить квінта, утворена двома натуральними флажолетами. Вся п’єса витримана у нюансах «тр-рррр».

«П'сса без назви» (1917-1918) створена лише за рік до Сонати для альта i фортепіано, коли Р. Кларк вже $є$ зрілою композиторкою та досвідченою альтисткою. Це відповідним чином позначилося на його якості він $є$ найскладнішим 3-поміж інших, написаних у той період. На нашу думку, заголовок «Без назви» продиктований імпровізаційним викладом п’єси i, крім того, передбачає певну свободу виконавця. На це, зокрема, вказує відсутність темпового позначення та нюансів (але при цьому у тексті відмічено агогіку та зустрічаються аплікатурні позначки у альтовій партіi).

На відміну від багатьох мініатюр Р. Кларк, у яких партії альта i фортепіано $є$ однаково важливими, зливаються в єдине ціле, тут альт знаходиться у центрі уваги, а фортепіано виконує швидше акомпануючу функцію. Якщо у попередніх та у більшості подальших мініатюр Р. Кларк альтова партія має вокальну природу, то у даному випадку природа сольної партії є суто інструментальною, навіть з елементами віртуозності. 3 усіх альтових творів «П’єса без назви» $є$ найбілыш наближеною до імпресіонізму, у чомусь навіть перекликаючись 3 «Прелюдією до пополудневого відпочинку фавна» К. Дебюссі, створюючи подібне відчуття безтурботності, бажання насолодитися кожним звуком.

Китайська головоломка («Chineese puzzle», 1921) написана як скрипкова мініатюра, на сьогоднішній день виконується здебільшого в альтовій версії. Не буде перебільшенням сказати, що цей твір є справжнім шедевром. Це один із прикладів втілення тяжіння європейських композиторів того часу до музики країн сходу. Причому, у даному випадку образ Китаю не є абстрактним - п’єса повністю заснована на пентатоніці.

Для зображення екзотичної країни потрібні відповідні екзотичні фарби. Композиторка знаходить найголовнішу з них - уся партія скрипки (альта) грається «ріzzicato» (подібні п’єси доволі рідко зустрічаються у сольному струнно-смичковому репертуарі). Доволі простий, на перший погляд, він вимагає високої майстерності від виконавця. Досягти якісного, повнозвучного звучання «ріzzicato» на скрипці набагато складніше, ніж на альті, віолончелі або контрабасі. Саме тому, на наш погляд, п’єса стала більш поширеною саме в альтовій версії. 
Нестандартно Р. Кларк підходить і до вирішення фортепіанної партії даного твору. Їй властиве «полярне» регістрове розміщення, коли права рука піаніста грає у регістрі, розташованому вище другої октави, а ліва - у контр-октаві, як це можна побачити у перших 9-ти тактах. У тактах 10-20 композиторка доручає фортепіано проведення теми в унісон через октаву. Все це надає інструменту дещо холодного, подібного до ксилофону звучання. Від самого початку п’єси Р. Кларк користується своїм улюбленим прийомом - розташуванням альтової партіїу регістрі між правою і лівою руками піаніста, ніби всередині звучання. У даному випадку це дозволяе не просто злитися звучанню обох тембрів, а взагалі створює відчуття якось нового, екзотичного інструменту.

П'єса написана у формі, наближеній до простої тричастинної. Хоча таке визначення $\epsilon$ досить відносним, оскільки вона заснована на постійному проведенні однієї теми, практично без змін. Середній розділ (такти 10-21) утворюється на основі передачі теми від альта до фортепіанота шляхом певної динамізації - появи акордів у альтових підголосках та перехід альта у високий регістр у тактах 17-20, із застосуванням «glissando».

Взагалі, п’єса утворює своєрідний гіпнотичний ефект, ніби дійсно переносячи нас у країни Сходу, де музика нерідко використовується як засіб введення людини у подібний стан.

Пасакалія на старовинну англійську тему (1941) стоїть окремо від інших альтових творів композиторки. Вона виділяється своєю трагічністю, що у певній мірі продиктовано самим жанром та обставинами створення. Твір був написаний під час Другої світової війни, коли Р. Кларк опинилася у вимушеній еміграції в Америці, повністю відірвана від батьківщини. Тут вперше серед іiі альтових творів проявилися неокласичні тенденції, які спираються на музику англійського бароко. Твір заснований на «Гімні №153» зі збірки «English Hymnal», авторство якого приписується англійському композитору XVI ст. Томасу Таллісу. Це своєрідна спроба знайти порятунок від хаосу війни у зверненні до творчості старих майстрів.

Існує версія, згідно якої твір міг бути написаний для участі у концерті пам'яті Френка Бріджа, котрий помер у 1941 р. (зрештою вона прийняла у ньому участь як виконавиця альтової партії у «Секстеті для струнних» Ф. Бріджа).

С декілька версій щодо того, кому присвячений твір (в нотах зазначено «to В.В.»). Сама композиторка говорила, що це були ініціали іiі племінниці. Та, своєї черги, цей факт не заперечувала, але до кінця не вірила у те, що «Пасакалію» було присвячено саме їй. Також існує версія, 
що ініціали «В.В.» належать Б. Бріттену. Видається цікавою наступна думка Л. Кертіс: «Якщо вона писала іiі просто як відповідь на смерть Бріджа, можливо, що вона позначила ії прізвиськом своєї племінниці, яке приваблювало інші „Б”, що на той час знаходилися у ії свідомості: Френк Брідж, її Батьківщина - Британія; та Бенджамін Бріттен, як символ наступного покоління композиторів Британії та майбутнє англійської музики - щоб це не було» [4, с. 35].

«Пасакалія» являє собою варіації на бассоостінато. Тема викладається у перших десяти тактах. Постійний рух чвертками та вісімками створює відчуття траурної ходи. Скорботний характер музики підсилюється тональністю c-moll, «підфарбованою» дорійським ладом, але ця скорбота має доволі стриманий, суто англійський характер. На зв'язок 3 традиціями бароко вказує також активне використання гамоподібних рухів. Варіації структурно не відокремлюються, а плавно переходять одна в одну, що сприяє цільності сприйняття твору. Р. Кларк знову максимально використовує можливості альта, проводячи тему у всіх регістрах, застосовуючи подвійні ноти, акорди. Фортепіанний супровід нагадує звучання органу, навіть оркестру. Взагалі, оркестральність є яскравою рисою даного твору.

«I'll bid my heart be still» (1944) - це останній альтовий твір Р. Кларк і передостанній у іiі творчому доробку взагалі. По-суті, він являє собою обробку оригінальної мелодії шотландської пісні. Риса, яка об'єднує всі проаналізовані твори - максимальне використання усіх можливостей початкового матеріалу - найяскравіше проявилася саме в цій, останній альтовій мініатюрі. Партія альта являє собою постійне повторення мелодії пісні. Рушійна сила розвитку належить фортепіанній партії, незважаючи на те, що вона не є тематично самостійною, будучи утвореною на основі виокремлення мотивів з альтової. Це $є$ доволі символічним, адже фактично завершуючи цим твором свою музичну кар'єру, Р. Кларк збиралася подальше життя повністю присвятити своєму чоловіку, який був піаністом. 3 приводу іншої «символічності» - тієї, яку закладено уназвіцього твору, цікаву думку знаходимо у Г. Люса: «У даному випадку вона просить заспокоїтися не тільки своє серце, але і перо» [5, с. 22].

У гармонічному плані твору хотілося б відмітити тяжіння до діатоніки, яке вперше зустрічається серед альтових п'єс, проаналізованих нами. Символічним $є$ i те, що твір закінчується на мажорній ноті: при основній тональності a-moll - це тризвук D-dur, який звучить особливо просвітлено. Взагалі, два останніх альтових твори композиторки «Пасакалія» та розглянута п’єса, - стали яскравим прикладом тенденції 
композиторів XX ст. до більшої ясності та кристалізації музичної мови, що до них вони вдаються у своїх заключних опусах, нерідко звертаючись при цьому до художньої спадщини попередніх епох.

Висновки. Стаття має важливе наукове значення, оскільки є одним 3 перших прикладів введення у вітчизняний науковий обіг постаті англійської композиторки та альтистки Р. Кларк - яскравої представниці англійського музичного відродження. Крім того, вона безпосередньо пов'язана 3 важливою, але практично недослідженою як у вітчизняному, так i y світовому музикознавстві сферою інструментальної мініатюри, зокрема альтової. У дослідженні піднімаються питання гендерної проблематики у рамках історії світової музики. Матеріал статті може стати основою для подальших досліджень у галузі альтової та інструментальної мініатюри взагалі, сприяти посиленню інтересу до творчості інших композиторів у цій сфері. Крім того, маємо сподівання, що дане дослідження стане своєрідним імпульсом для активного залучення вищезгаданих творів до концертного репертуару вітчизняних альтистів. Це, з одного боку, сприятиме його урізноманітненню, а 3 іншого - популяризації даних творів і як наслідок - відродженню імені Ребекки Кларк, приверненню уваги до інших сфер іiі композиторського доробку.

1. Зенкин К.В. Фортепианная миниатюра и пути музыкального романтизма. Автореферат диссертаџии на соискание ученой степени доктора искусствоведения. М.: Московская государственная консерватория им. П. И. Чайковского, 1996. 54 с.

2. Карапінка М.3. Камерно-ансамблева альтова соната у творчості англійських композиторів початку ХХ ст. Л.: Музикознавчі студії: 3б. статей, вип. 35, 2015. с. 113-125.

3. Curtis L. A case of identity: rescuing Rebecca Clarke. The Musical Times, 15-21. May 5, 1996.

4. Curtis L. A Rebecca Clarke reader. The Rebecca Clarke Society, Inc. 2004.

5. Luce Gregory R.British viola repertoire of the first half of the twentieth century. Dissertation submitted to the Faculty of the Graduate School of the University of Maryland, College Park, in partial fulfillment of the requirements for the degree of Doctor of Musical Arts. 2015.

6. Rebecca Clarke. List of works URL: https://www.rebeccaclarke.org/worksi/ (dama звернення: 30.01.2018).

7. Riley Maurice W.The history of the viola. V. I. Braun-Brymfield, Ann Arbor, Michigan, USA. 1993.

\section{References}

1. Zenkin, K.V. (1996). The piano miniature and the ways of development of the European romanticism: Author's thesis [Fortepiannaia miniatiura i puti muzykalnogo romantizma: avtoref. dis. ... kand.iskusstv.]. Moscow, The Moscow Tchaikovsky Conservatory. 54 p.

2. Karapinka, M.Z. (2015). The chamber viola sonata in the creativity of English composers of the beginning of the XX-th century [Kamerno-ansambleva altova sonata u tvorchost anhliiskykh kompozytoriv pochatku XX stolittia], L'viv. The courses of the musicologists, №35, pp. 113-125. 
3. Curtis, L. (1996, May 5). A case of identity: rescuing Rebecca Clarke, The Musical Times, pp. 15-21.

4. Curtis, L. (2004). A Rebecca Clarke reader, The Rebecca Clarke Society, Inc., 241 p.

5. Luce, Gregory R. (2015). British viola repertoire of the first half of the twentieth century: dissertation, Faculty of the Graduate School of the University of Maryland, College Park, $29 \mathrm{p}$.

6. Rebecca Clarke. List of works. Available at: https://www.rebeccaclarke.org/worksi/ [Accessed 30.01.2018].

7. Riley Maurice W. (1993). The history of the viola, V. I. Braun-Brymfield, Ann Arbor, Michigan, USA, 396 p. 